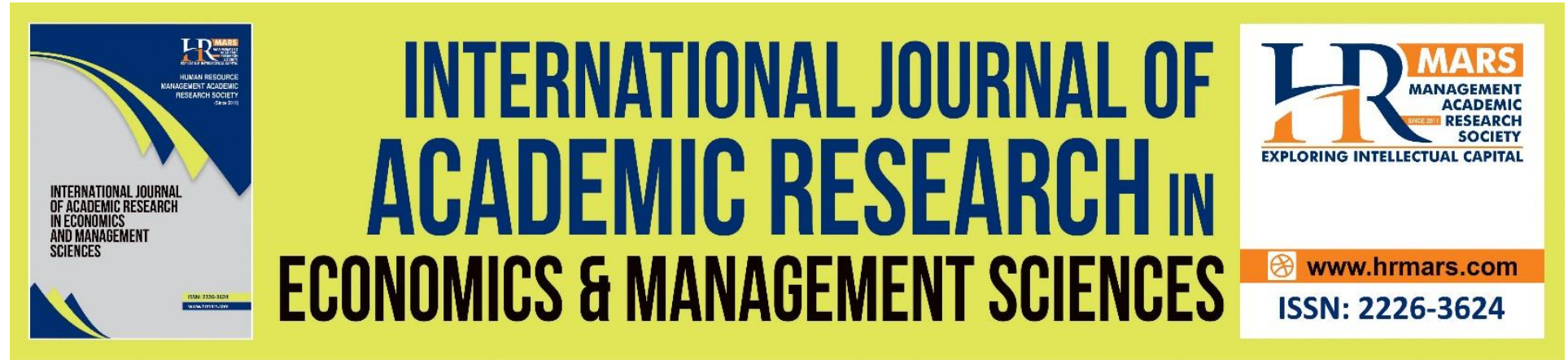

\title{
Economics and Environment Assessment of Microgrid Configurations for Rural Area with Standalone and Integrated Energy Storage System
}

\author{
Dahlan, N. Y., Mahmod A. N.
}

To Link this Article: http://dx.doi.org/10.6007/IJAREMS/v10-i4/11995

DOI:10.6007/IJAREMS/v10-i4/11995

Received: 28 October 2021, Revised: 29 November 2021, Accepted: 09 December 2021

Published Online: 26 December 2021

In-Text Citation: (Dahlan \& N., 2021)

To Cite this Article: Dahlan, N. Y., \& N., M. A. (2021). Economics and Environment Assessment of Microgrid Configurations for Rural Area with Standalone and Integrated Energy Storage System. International Journal of Academic Research in Economics and Management and Sciences, 10(4), 70-82.

\section{Copyright: (C) 2021 The Author(s)}

Published by Human Resource Management Academic Research Society (www.hrmars.com)

This article is published under the Creative Commons Attribution (CC BY 4.0) license. Anyone may reproduce, distribute, translate and create derivative works of this article (for both commercial and non-commercial purposes), subject to full attribution to the original publication and authors. The full terms of this license may be seen at: http://creativecommons.org/licences/by/4.0/legalcode

Vol. 10, No. 4, 2021, Pg. 70 - 82

Full Terms \& Conditions of access and use can be found at http://hrmars.com/index.php/pages/detail/publication-ethics 


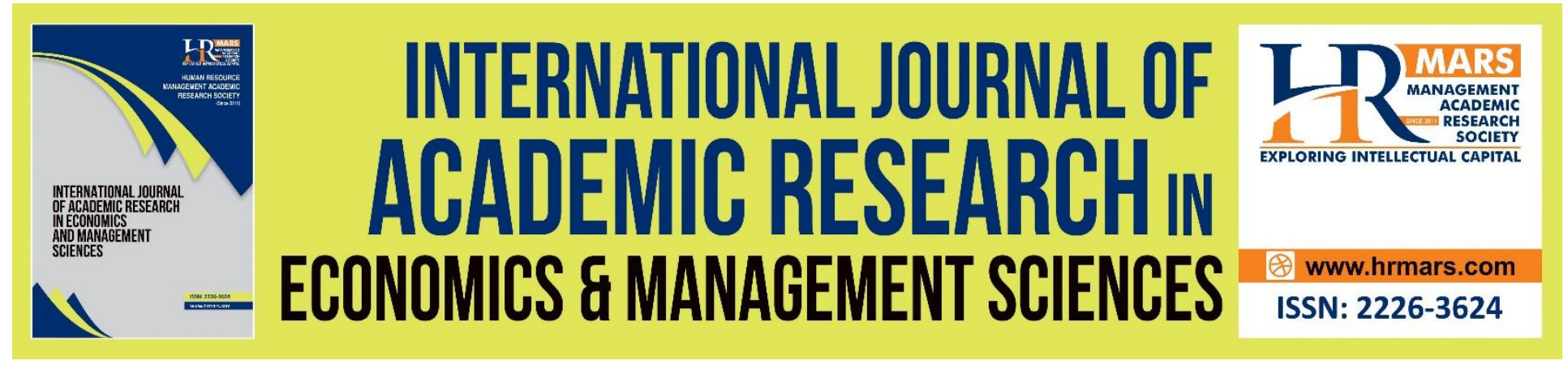

\title{
Economics and Environment Assessment of Microgrid Configurations for Rural Area with Standalone and Integrated Energy Storage System
}

\author{
Dahlan, N. Y., Mahmod A. N. \\ Faculty of Electrical Engineering, Universiti Teknologi Mara (UiTM), 40450, Shah Alam, Selangor, \\ Malaysia
}

\begin{abstract}
Nowadays, with the rising in electricity demand, Energy Storage System (ESS) plays an important role in solving power crisis especially in small area such as an island. The microgrid concept with energy storage system (ESS) has rising its popularity and interest because it capable to store energy during off-peak hours and supply it back to the grid during peak demand. The objective of this paper is to optimize energy storage system in a real case during peak demand in rural area which is located in a rural area in Tanjung Labian, Sabah. The optimization was modelled and analysed using HOMER by including renewable and conventional energy resources such as solar PV, diesel generators, batteries, and inverter. This paper is divided into two sections. The first section is to investigate the optimum microgrid system by modelling combination of renewable energy and ESS. The optimization model includes parameters such as life cycle, reliability, cost, and size that would give the minimum cost of microgrid system. In the second section, a further investigation was carried out by determining the economics of energy from the best combination of renewable energy and ESS. The results shown that the present of ESS in the system able to reduce the cost and dependency on standalone system through the optimized diesel-PV-battery system modelling having an approximation of $20 \%$ less cost as to compared without batteryavailable system. The perfection of modelling ESS with optimization characteristics will be the key features to the next generation technologies.
\end{abstract}

Keywords: Optimization, HOMER, Energy Storage System (ESS), Economics.

\section{Introduction}

Microgrid is known as a small-scale grid that able to supply load with different combination of resources and can be connected or isolated from the utility grid. During peak demand, microgrid is usually supported by generator or renewable energy such as solar, wind turbine and often used as backup power or supplement the main power grid. It is usually difficult to install power grid from the main land to far island due to various issues including transportation, economics and reliability issues. Microgrid can be found in certain places such in university, hospital, military 
bases, islanding, airport and large industrial facilities. The rising of population growth rate and urbanization levels causes increasing in electricity demand and emission of carbon dioxide emission. Therefore, application of renewable energy leads to more sustainable and minimizes fuel consumption and harmful gases emission (Aghamohammadi \& Abdolahinia, 2014).

To reduce supply crisis and meet the growing demand, renewable energy (RE) with energy storage system (ESS) has become an alternative to act as back up during peak demand. Energy storage system will assist renewable energy in various ways, especially helping the system stability during power crisis. The stability of the system will give serious impact on the overall electric system by storing energy during off-peak and minimize cost (HOMER, 2020). Energy storage is a core component in most remote supply systems, and it needs to be considered in order to ensure the safe and efficient sustainable during operation. There are numerous types of energy storage are available commercially in various stage of implementation. The main type of energy storage can be classified such as mechanical, thermal or electrical type (Kassam, 2010; Kerdphol et al., 2015). Each type has its own properties time to charge or discharge, the lifetime and cost operated system. Hence, it is important to know each characteristic and identify on how energy storage capable to minimize operation at minimum cost. Hence, the needs suitable combination of energy storage and renewable energy is important to ensure reliable power supply at load demand.

There are many types of modern optimization method to find the best microgrid system such as size optimization, lifetime characteristics or economic performance by net metering scheme (Faisal et al., 2018; Li \& Hennessy, 2013; Saviuc et al., 2019). However, many studies do not consider the reliability of ESS as electricity back-up during power crisis and the need of ESS in microgrid. Moreover, they stated that by installing ESS technology in microgrid is inefficient due to various issue, such as charging or discharging cost, reliability, life cycle and overall cost management. In addition, the inclusion of ESS is not attractive especially when price electricity in the smart grid is very low.

A study of the effect of heat recovery factor in three different scenarios of combined heat and power (CHP) have carried out by using HOMER in a residential area located in Iran (Somayeh et al., 2018; Mehdi et al., 2018). The scenarios include generator and boiler which consume diesel as the first scenario, while using natural gas as their fuel done in second scenario. The third scenario implemented by diesel being used in a generator and the boiler consumed natural gas. The first case has been concluded as the most economical while the third scenario (hybrid microgrid) surpassed the environmental concerns as to compared to the remaining scenarios with the least carbon dioxide production of $3604 \mathrm{~kg} / \mathrm{year}$.

Meanwhile, a study in Karachi of technical-economic-environmental sensitivity analysis of electricity production and thermal loads of residential areas through off-grid wind-solar-fuel cell system considering the spill effect of emission penalty and annual interest rate on cogeneration of electricity production has been carried out (Mehdi et al., 2018; Habib Ur Rahman et al., 2018). The use of dump loads for converting excess electricity into heat and also heat recovering in fuel cells. This paper produced a great potential for supplying sufficient power and heat by renewable energies and having dump loads as an essential role to provide the thermal demand.

Therefore, this paper will examine the optimization of energy storage system in the microgrid by using HOMER software. The U.S National Renewable Laboratory (NREL) has developed software named HOMER to make easier for user to evaluate any possible 
configurations of optimization and sensitivity analysis. In HOMER, user able to input power consumption in hourly or monthly data. It also able to input the load demand in daily basis, the solar radiation and daily temperature. This allows users to evaluate optimization of microgrid in various factors such the renewable penetration, the economics, environmental-friendly and the stability. HOMER also able to simulate from small to large scale paper (Singh \& Tiwari, 2017).

\section{Problem Formulation}

Simulation is performed to find the best optimization model which able to operate at lowest operating cost. If the results are not in the best optimization, the new combinations of RE+ESS are modelled. The optimization parameters include the size of components, capacity, life cycle, economics, and reliability. Model of each component in the system such as PV, battery and diesel generator are shown below.

\section{System Modelling}

PV Model: The output power of PV module can be determined by the rated capacity of the PV array in its power output under standard test conditions, solar radiation and ambient temperature.

$P_{P V}=P_{\text {stc }} \frac{G_{c}}{G_{\text {stc }}}\left[1+\alpha\left(T_{c}-T_{\text {stc }}\right)\right]$

$P_{P V}$ is output of the PV array, $G_{s t c}$ is solar radiance under standard condition, $1 \mathrm{~kW} / \mathrm{m}^{2} . G_{c}$ is solar irradiance on the PV array, $\alpha$ is the temperature coefficient of power. $T_{c}$ is PV cell temperature and PV $T_{\text {stc }}$ temperature are $25^{\circ} \mathrm{C}$.

Lead-Acid Battery Model: The lead-acid battery plays an important role in microgrid system. The operating strategy of battery give an impact to overall operation. The SOC of battery at a certain time should be in range.

$S O C_{\min } \leq S O C \leq S O C_{\max }$

In which, SOC has upper and lower limit which $\mathrm{SOC}_{\min }$ and $\mathrm{SOC}_{\max }$ respectively. In addition, there is also a limit for battery output power. $P_{\text {cha-max }}$ is requirement for charging while $P_{\text {discha-max }}$ is the maximum for discharging. When the battery is charging, $P_{b a t}$ is positive. Otherwise, $P_{b a t}$ is negative when discharging.

$P_{\text {cha-max }} \leq P_{\text {bat }} \leq P_{\text {discha-max }}$

Diesel Generator Model: Diesel generator is used as backup power when there is not enough output from PV. The fuel curve of generator is assumed as straight line. The given equation is a generator's fuel consumption in units/hour as a function of its electrical output.

$F_{0} \times P_{\text {rated,gen }}+F_{1} \times P_{g e n}$ 
$F_{0}$ and $F_{1}$ is the fuel curve intercept and slope coefficient respectively. $P_{\text {rated-gen }}$ is the rated capacity of the generator and $P_{\text {gen }}$ is the electrical output power.

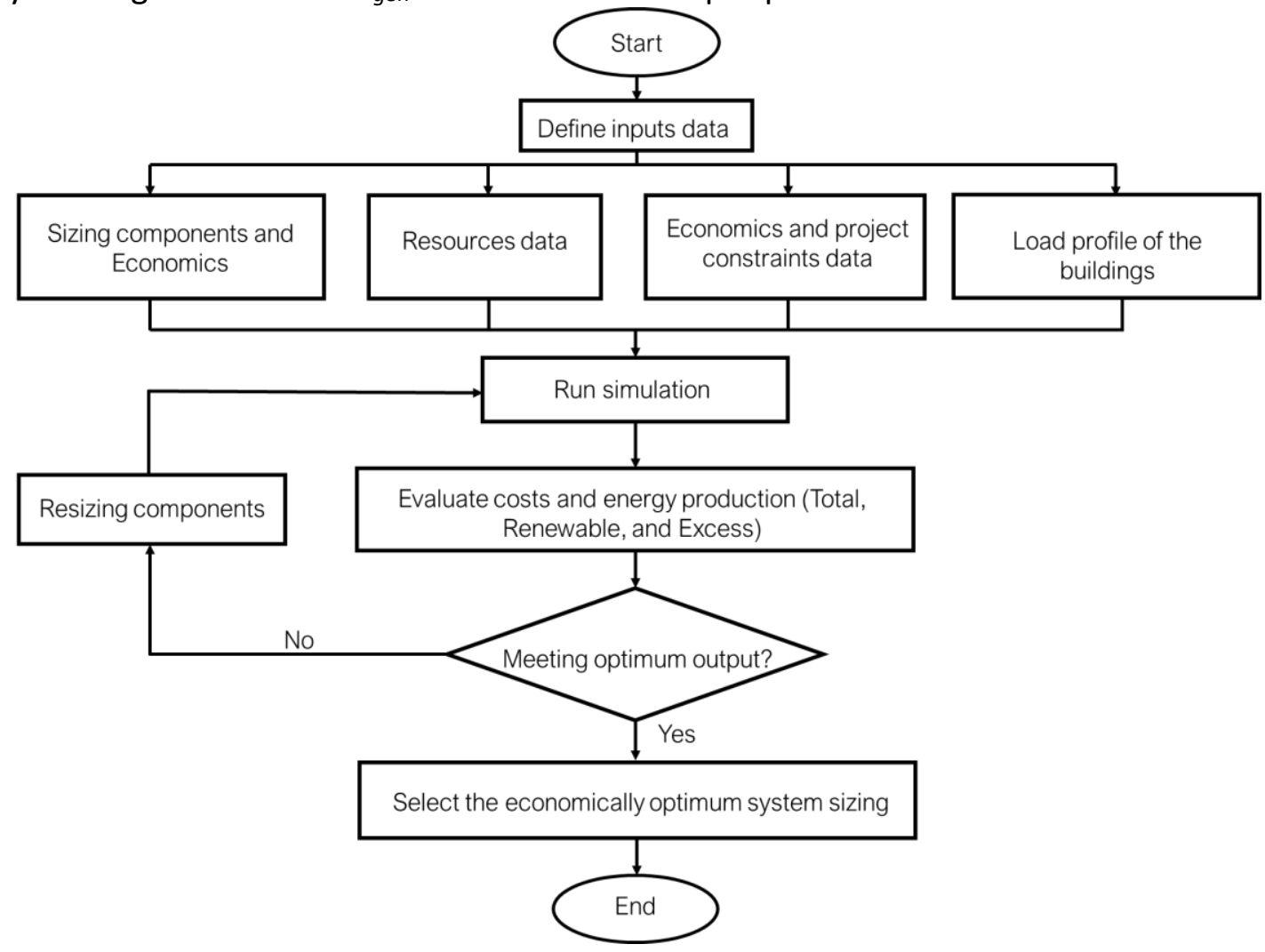

\section{Objectives Function and Constraints}

In HOMER, the best possible system configuration is the one that able to operate at minimum cost. In finding the optimal system, it includes the consideration such in the dispatch strategies system, size and capacity of the component. Therefore, in order to determine the optimal value that suits best the system, the following constraint need to be satisfied:

Generation cost: The generation comprises of two parts which the cost from diesel generator and from the renewable energy. In HOMER, the generator fuel consumption is as follow:

$$
F=F_{0} P_{\text {rated_gen }}+F_{1} P_{\text {gen }}
$$

$F_{0}$ denotes as the intercept confident of fuel curve, $F_{1}$ is the gradient of the curve, $P_{\text {rated- }}$ gen is the rated capacity and $P_{\text {gen }}$ is the generator electrical output. In HOMER, the generation is calculated as:

$C_{\text {gen,fixed }}=C_{\text {om,gen }}+\frac{C_{\text {rep,gen }}}{R_{\text {gen }}}+F_{0} Y_{\text {gen }} C_{f u e l, e f f}$

For renewable energy, the generation cost is $C_{\text {gen,fixed }}$. The operating and maintenance equipment for generation life is $C_{o m-r e n}$ and $C_{\text {rep,gen }}$ respectively. The intersection fuel curve coefficient is denoting as $F_{0}$, the generator lifetime in hours is $R_{\text {gen, }}$ the generator capacity is label 
as $Y_{\text {gen }}(\mathrm{kW})$, While $C_{\text {fuell, eff }}$ is included the pollution generated cost due operation generation cost.

In HOMER, the properties storage life indicates the storage life is depends on lifetime throughput. To measure the life span of batteries, HOMER observed energy cycling passes it. The following equation is to calculate battery life in years:

$$
R_{\text {batt }}=\min \left(\frac{N_{\text {batt }} Q_{\text {lifetime }}}{Q_{\text {thrpt }}}\right), R_{\text {batt }, f}
$$

The number of battery bank is label as $N_{\text {batt }}, Q_{\text {liferime }}$ is the lifetime of battery and $Q_{\text {thrpt }}$ is the summation of total energy cycle through battery bank within one year, and $R_{b a t t, f}$ is the maximum life battery life. HOMER calculates the wear cost of battery is as follow:

$\mathrm{C}_{\text {batt }}=\frac{\mathrm{C}_{\text {reppbatt }}}{N_{\text {batt }} \cdot Q_{\text {lifetime }} \cdot \sqrt{\eta_{n}}}$

$\mathrm{C}_{\text {reppbatt }}$ is the replacement cost of the storage bank, $N_{\text {batt }}$ is the number of batteries in storage bank and $Q_{\text {lifetime }}$ is the lifetime in each single storage [kWh] and ${\sqrt{\eta_{n}}}_{n}$ is a roundtrip efficiency in fractional or in average of $80 \%$.

In addition, the constraints in (1), (2) and (4) should also be satisfied.

\section{Evaluation Criteria}

In the HOMER, it provides analysis in economical based on the framework of life cycle cost (LCC) The LCC depends on capital cost, replacement cost and operating maintenance cost. HOMER able to perform simulation to find the optimum cost and design. The total net present cost determined by HOMER is as follow:

$\mathrm{NPC}=\frac{C_{t o t}}{C R F\left(i, T_{p}\right)}$

$C_{\text {tot }}$ is the total annual cost of the system (\$/year), $\mathrm{i}$ is the annual interest rate and $T p$ is the lifetime of operation, while $C R F$ is the capital recovery factor which can be defined as:

$$
\operatorname{CRF}(\mathrm{i}, \mathrm{n})=\frac{i(1+1)^{n}}{(1+i)^{n^{-1}}}
$$

$n$ is representing the number of years. Then, the salvage cost (SV) is calculated as:

$\mathrm{SC}=\mathrm{C}_{\mathrm{RC}} \frac{T_{\text {rem }}}{T_{\text {com }}}$

$\mathrm{C}_{\mathrm{RC}}$ is the equipment replacement cost. $T_{\text {rem }}$ is equipment remaining lifetime(year) and $T_{\text {com }}$ is the component period life (year). The levelized of COE is as following:

$\mathrm{COE}=\frac{C_{t o t}}{E_{\text {tot }}}$ 
$E_{\text {tot }}$ denotes as the total annual electricity consumption ( $\mathrm{kWh} /$ year).

\section{System Design}

This project test bed was in Tanjung Labian, Sabah. It is a small island located at the eastern side of Sabah with the latitude $5.10^{\circ} \mathrm{N} / 119.13^{\circ} \mathrm{E}$. The main source incomes for the islanders are timber, tourism and exporting seafood (Nfah \& Ngundam, 2008) as shown in figure 1 . The system has been designed to include the following technologies, PV systems, converter and diesel generator to acts as back up supply.

Table 1: Site specification

\begin{tabular}{lll}
\hline Site & 800 houses \\
\hline Location & $\begin{array}{l}5.10{ }^{\circ} \mathrm{N} \text { latitude, 119.13 }{ }^{\circ} \mathrm{E} \\
\text { longitude }\end{array}$ \\
\hline Average load & $160.11 \mathrm{~kW}$ \\
\hline Peak load & $416.98 \mathrm{~kW}$ \\
\hline
\end{tabular}

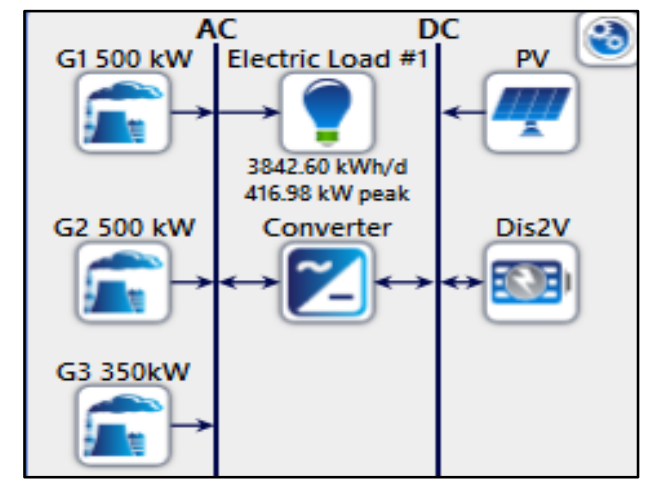

Figure 1: Schematic for Microgrid system

\section{Load Demand}

In remote areas, usually the local spent their whole time outdoors since their main sources of income comes from fishing, tourism and exporting seafood. The use of the electricity does not high as in urban areas. The uses of load started to increase at noon as the family members will come home to have lunch. However, the peak demand will be at night when all the family members are at home. The demand data were gathered from (Nfah \& Ngundam, 2008). The data had been modified to provide a more accurate portrayal demand for load modelled period. The daily load profile is shown in figure 2 can be observed that the load varies throughout the day. In the morning, the demand is low. However, as the day passes, the demand is rising, and it noticed the peak demand was at night. Random variability factor has been set to HOMER in order to estimate differences in each day, it is known as day-to-day variability and time-to-step-time variability. Malaysia is tropical country which do not have various season. Therefore, approximately $5 \%$ has been set for the variability. 


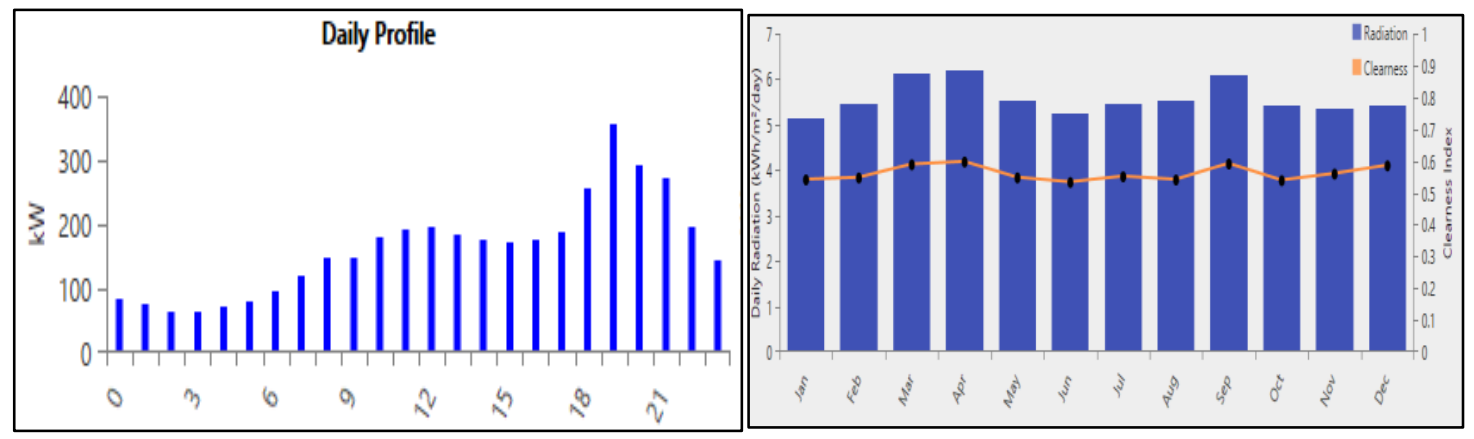

Figure 2: Daily Load Profile

Figure 3: Solar Radiation Data

\section{Solar Radiation and Temperature}

The data of solar radiation was provided by Malaysian Metrological Department which can be downloaded through HOMER. Solar radiation for Tanjung Labian was selected and the data showed that the range of solar radiation is between $4.8 \mathrm{kWh} / \mathrm{m}^{2}$ to $5.57 \mathrm{kWh} / \mathrm{m}^{2}$. In figure 3 , it can be seen that the solar estimated annual average scale for Pulau Banggi is $5.57 \mathrm{kWh} / \mathrm{m}^{2}$. Generally, the annual average temperature for Tanjung Labian is $26.3^{\circ} \mathrm{C}$. The temperature data is downloaded from NASA.

\section{System Components}

Tanjung Labian power system is implemented with several components such diesel generator, PV array, batteries and converter. It is about to supply electricity for 800 houses (Nfah \& Ngundam, 2008).

\section{Diesel Generators}

Diesel generator will be used to meet the demand when there is no output from PV panel and batteries (Hossain et al., 2017). The recent diesel price in Malaysia is RM 2.18 per litre (\$ 0.7 per litre). The capital cost and replacement cost for this paper is $220 \$ / \mathrm{kW}$ while the maintenance cost is $0.030 \$ / \mathrm{kW}$. The generator price is stated by (Anwari et al., 2012). As in (Shaahid \& ElAmin, 2009), the diesel price is depending on locations; where in the remote area the fuel price could be 1.5 times higher than normal prices. This is due to the expensive cost of transportation to the location.

\section{PV array and Converter}

PV system is used to supply base load during daytime and at the same time charging the energy storage. The capital cost and replacement cost for PV is $2000 \$ / \mathrm{kW}$ and the maintenance cost are $10 \$ /$ year (Anwari et al., 2012). The used of converter is to convert electrical energy to desired forms. The rated of converter is depends on PV array to ensure to fully supply PV. The capital cost and replacement cost are $890 \$ / \mathrm{kW}$ and $800 \$ / \mathrm{kW}$ respectively while the maintenance cost is 10 $\$ / k W($ Anwari et al., 2012). 


\section{Battery Energy Storage}

Battery acts as backup to supply electricity during peak demand and during nighttime. The battery consists of 6 string with 240 batteries units. The capital cost of battery is $1200 \$ /$ unit and 1170 \$/unit for replacement.

\section{Operating Strategies}

In HOMER, there are two main operating strategies can bet set which are cycle charging (CC) and operating charging (OC). In cycle charging, diesel generator is used to supply the base demand also needed to charge the battery. Generator operates at its full maximum capacity, if there is excess electricity it will be used to charge the battery. However, in this paper load following was assumed to operate the system. In load following strategy, PV is used to supply the base load and charging the battery until it fully charged. If there is not enough power, the battery still able to meet the demands until it reaches the certain set-point of charges. Only after that, the generator will take place to supply the loads. Generator is use as backup power. Load following strategies is an ideal system with a lot of RE power.

\section{Result and Discussion}

The results will be discussed by comparing operating strategies of different system configurations such standalone, existing diesel/PV/battery system, existing system diesel/PV without battery and the optimized system. The results will include all the technical, economical and environment factors. The comparison of results of each system is provided in Table II. This study presents $6 \%$ of interest rate to the diesel price and investment cost with paper lifetime 25 years. The results for each part are separately in section 5.1, 5.2 and 5.3.

\section{Optimization Results}

\section{Standalone System}

From the results in Table II, it can be figured out that the lowest net present cost (NPC) for all system with $\$ 5,105.503$ can be obtained in standalone diesel system. The system cost will be high due to installing RE requires lots of cost. In this system, the largest generator is used to supply the load demand and the other generator will act as back up. From Table III it can be seen, generator 1 was served the base load. The other generator will be on standby, if generator 1 unable to meet the demand, generator 2 will take immediate action backup generator 1 , generator 3 will followed as well. Since the first generator is $500 \mathrm{~kW}$, it supplies all the demand as the peak demand is $416.98 \mathrm{~kW}$ in this system. Renewable energy fraction is $0 \%$ as the system do not use solar photovoltaic. This shows total electricity production is $100 \%$ comes from diesel generator 1,625,623 kWh/yr.

\section{Existing Diesel/PV/ Battery System}

PV arrays produce large amount of electricity which $66.1 \%$ of the energy production can be noticed in Table III. During the daytime, the PV arrays will supply the base load and at the same time charging the energy storage system. Meanwhile, during nighttime, if the battery could not supply the demand, generator 1 will take an action and supply the load. Hence, the largest generator $1(500 \mathrm{~kW})$ produce $33.9 \%$ of energy production. Another generator will be on standby. The NPC and COE for this system is twice amount compared to stand alone system which 
$\$ 7,765,982$ and $\$ 0.3515$ respectively. The NPC is higher due to present of RE system. However, the operating cost is lower by $\$ 249,590.70$. Renewable fraction for this system is $28.3 \%$. However, in this system the excess electricity is $50 \%$ per year which it can still be reduced by optimizing the system.

\section{Existing System Diesel/PV without Battery}

This condition is developed to study the advantages or disadvantages system without battery. The results show in table II, the Net Present Cost, operational and LCOE is higher than existing system with includes battery i.e. $\$ 9,106,820, \$ 352,993.30$ and $0.4122 \$ / \mathrm{kWh}$ respectively. This combination is the most expensive among all system because the generated power from PV is not being used fully. The excess electricity which can be used to charge battery is consider as loss since this system do not include energy storage system. Hence, when PV cannot meet the demand and there is no storage to store energy, generator need to be ON to replace the PV supply the load. In addition, the $\mathrm{CO}_{2}$ emission from generator is higher due to running hours of generator 1 is longer than system with batteries. This could cause air pollution. The analysis does not impose the penalty cost for pollution.

\section{Optimizing System PV/Diesel and Battery}

In the optimum system configuration, the selection of sizing component is observed less than the existing system. The net present cost is $\$ 5,981,107$ which are lower than the existing system where $\$ 7,765,982$. The operational cost and LCOE is $\$ 278,229.20$ and $0.2707 \$ / \mathrm{kWh}$ respectively. The system uses 240 batteries unit. In addition, the excess electricity for this system is only $14.8 \%$. Hence, this optimum system shows a huge different in cost and operating due to less PV and generator capacity use.

Table 2: Total cost of the system

\begin{tabular}{|c|c|c|c|}
\hline Description & NPC (\$) & $\begin{array}{l}\text { Operational Cost } \\
\text { (\$) }\end{array}$ & $\begin{array}{l}\text { LCOE } \\
\text { (\$/kWh) }\end{array}$ \\
\hline Standalone Diesel & $5,105,503$ & 319,137 & 0.2311 \\
\hline Existing Diesel/PV/Battery system & $7,765,982$ & $249,590.70$ & 0.3515 \\
\hline $\begin{array}{l}\text { Existing Diesel/PV/ without Battery } \\
\text { system }\end{array}$ & $9,106,820$ & $352,993.30$ & 0.4122 \\
\hline Diesel/PV/battery & $5,981,107$ & $278,229.20$ & 0.2707 \\
\hline
\end{tabular}

\section{Operating Strategies}

The technical challenging part for the systems is to decide their operating strategies. The simulation was carried out from the optimizing diesel/PV and battery system with two different operating strategies. Table IV shows the Net Present Cost (NPC), operating and LCOE for load following is cheaper than cycle charging dispatch by $\$ 5,964,988, \$ 277,226.90$ and $0.270 \$ / \mathrm{kWh}$ respectively. This is because in load following; PV is used to supply the base load and charging the battery. The use of generator is load following only enough to feed the load. 
INTERNATIONAL JOURNAL OF ACADEMIC RESEARCH ECONOMICS AND MANAGEMENT SCIENCES

Vol. 10 , No. 4, 2020, E-ISSN: 2226-3624 ㄷ 2020 HRMARS

Table 3: Overall System Performance

\begin{tabular}{|c|c|c|c|c|c|c|}
\hline Type of System & Component & $\begin{array}{l}\text { Rated } \\
\text { Capacity } \\
(\mathrm{kW})\end{array}$ & $\begin{array}{l}\text { Production } \\
(\%)\end{array}$ & $\begin{array}{l}\text { Production } \\
\text { kWh/yr }\end{array}$ & $\begin{array}{l}\text { Running } \\
\text { hours } \\
\text { (h/yr) }\end{array}$ & $\begin{array}{l}\mathrm{CO}_{2} \\
\text { emission }\end{array}$ \\
\hline \multirow{4}{*}{$\begin{array}{l}\text { Standalone } \\
\text { system }\end{array}$} & G1 & 500 & 100 & $1,625,623$ & 8,760 & \multirow{4}{*}{$1,200,906$} \\
\hline & $\mathrm{G} 2$ & 500 & 0 & 0 & 0 & \\
\hline & G3 & 350 & 0 & 0 & 0 & \\
\hline & Total & 1350 & 100 & & & \\
\hline \multirow{5}{*}{$\begin{array}{l}\text { Existing } \\
\text { Diesel/PV/Battery } \\
\text { system }\end{array}$} & PV & 1200 & 66.1 & $1,959,918$ & 4,380 & \multirow{5}{*}{740,163} \\
\hline & G1 & 500 & 33.9 & $1,006.239$ & 5,249 & \\
\hline & $\mathrm{G} 2$ & 500 & 0 & 0 & 0 & \\
\hline & G3 & 350 & 0 & 0 & 0 & \\
\hline & Total & 1350 & 100 & & & \\
\hline \multirow{5}{*}{$\begin{array}{l}\text { Existing Diesel/PV } \\
\text { without Battery }\end{array}$} & PV & 1200 & 56.2 & $1,959.0917$ & 4,380 & \multirow{5}{*}{$1,138,714$} \\
\hline & G1 & 500 & 43.8 & $1,529,139$ & 8,735 & \\
\hline & G2 & 500 & 0 & 0 & 0 & \\
\hline & G3 & 350 & 0 & 0 & 0 & \\
\hline & Total & 1350 & & & & \\
\hline \multirow{5}{*}{$\begin{array}{l}\text { Optimized } \\
\text { Diesel/PV/Battery } \\
\text { system }\end{array}$} & PV & 400 & 41.4 & 653,306 & 4,380 & \multirow{5}{*}{836,019} \\
\hline & G1 & 300 & 36.6 & 577,781 & 5,769 & \\
\hline & $\mathrm{G} 2$ & 200 & 18.0 & 284,622 & 1,092 & \\
\hline & G3 & 200 & 3.95 & 62,404 & 434 & \\
\hline & Total & 1000 & 100 & & & \\
\hline
\end{tabular}

Table 4: Total cost for dispatch strategies

\begin{tabular}{|c|c|c|c|c|}
\hline Dispatch Strategy & NPC (\$) & $\begin{array}{l}\text { Operating } \\
\text { (\$) }\end{array}$ & Cost & LCOE (\$/kWh) \\
\hline Load Following & $5,964,988$ & $277,226.90$ & & 0.2700 \\
\hline Cycle Charging & $6,132,705$ & $287,874.00$ & & 0.2776 \\
\hline
\end{tabular}

\section{Sensitivity Analysis}

\section{High Diesel Price}

The diesel price in remote areas can be high due to its location and the expensive transportation. The diesel price is varied from $0.7 \$ / L$ to $3.00 \$ / L$. The growth demand was assumed as $5 \%$ per year, and the results show as the fuel price increase. The NPC, operating and LCOE are expected to increase. However, the fuel price will continue increase but the total cost can be reduced as the new development technology of will lead to reduce PV and batteries prices. Decreasing in PV and batteries price will lead to the less dependence on standalone system.

\section{Battery Sizing}

Also, analysis on battery have been observed. The present of storage system is important, to ensure the stability on the system especially during the peak demand. The size of batteries gives 
an impact on NPC value. Increasing number of batteries, the value of NPC will be higher as the addition battery will add up cost to the NPC and the operational cost. In order to operate optimally, choosing the size of battery should be aligned with the usage of load demand. The size of battery has been varied from 60- 360 units. In this study, 240 units of batteries with $40 \%$ SOC is the optimum for the system with 7 years of lifetime.

\section{Environmental Impact}

The usage of diesel has given negative impact to environment and human health. From the Table $\mathrm{V}$, the $\mathrm{CO}_{2}$ emission in the standalone system shows the highest rate compared to other systems with 1,200,906 kg/year. The diesel price gives an impact in choosing optimization system, the optimization would be to standalone system if the diesel price is $0.7 \$ / L$. However, the standalone system will only be feasible when the increasing in diesel price starting $1.06 \$ / \mathrm{L}$. Then, system with PV and battery is the cheapest among all. Therefore, the existing of RE sources in the system has improved economical and environment characteristics. As seen in results, the present of PV and energy storage system reduced the amount of harmful emission release.

Table 5: System behaviour for dispatch strategies

\begin{tabular}{lll}
\hline $\begin{array}{l}\text { Pollutant } \\
\text { (kg/yr) }\end{array}$ & Standalone System & $\begin{array}{l}\text { Existing } \\
\text { Diesel/PV/Batteries }\end{array}$ \\
\hline Carbon Dioxide & $1,200,906$ & 740,163 \\
\hline $\begin{array}{l}\text { Carbon } \\
\text { Monoxide }\end{array}$ & 6,213 & 3,829 \\
\hline $\begin{array}{l}\text { Unburned } \\
\text { Carbon }\end{array}$ & 330 & 203 \\
\hline Matter & 53.1 & 32.7 \\
\hline Sulfur dioxide & 2,936 & 1,809 \\
\hline Nitrogen oxide & 1,191 & 734 \\
\hline
\end{tabular}

\section{Conclusion}

This study investigates the economic analysis in different system in Tanjung Labian by using HOMER. It has shown that:

- the standalone system is the best economical compared to existing PV/Diesel/Battery system.

- the present of RE and storage system reduced the emission of harmful gasses.

- considering dispatch strategy, load following is the best for option where it produces more renewable penetration, cycle charging is efficient when renewable penetration is less.

- the sensitivity results are conducted based on certain parameters which are diesel price, PV size, load demand growth, battery sizing and environmental impact. It predicts the trends of RE sources in future and become less dependent on standalone system.

- this study has shown that by including energy storage to store energy capable to minimize cost, reduce the excess energy also the dependence on diesel generator. 


\section{References}

Aghamohammadi, M. R., \& Abdolahinia, H. (2014). A new approach for optimal sizing of battery energy storage system for primary frequency control of islanded Microgrid. International Journal of Electrical Power and Energy Systems, 54, 325-333.

https://doi.org/10.1016/j.ijepes.2013.07.005

Anwari, M., Rashid, M. I. M., Muhyiddin, H. T. M., \& Ali, A. R. M. (2012). An evaluation of hybrid wind/diesel energy potential in Pemanggil Island Malaysia. 2012 International Conference on Power Engineering and Renewable Energy, ICPERE 2012, July. https://doi.org/10.1109/ICPERE.2012.6287244

Faisal, M., Hannan, M. A., Ker, P. J., Hussain, A., Mansor, M. Bin, \& Blaabjerg, F. (2018). Review of energy storage system technologies in microgrid applications: Issues and challenges. IEEE Access, 6(1), 35143-35164. https://doi.org/10.1109/ACCESS.2018.2841407

HOMER. (2020). Chapter: 3 HOMER modeling 3.1. 55-81.

Hossain, M., Mekhilef, S., \& Olatomiwa, L. (2017). Performance evaluation of a stand-alone PVwind-diesel-battery hybrid system feasible for a large resort center in South China Sea, Malaysia. Sustainable Cities and Society, 28, 358-366.

https://doi.org/10.1016/j.scs.2016.10.008

Kassam, A. (2010). HOMER Software: Training Guide for Renewable Energy Base Station Design Mobile for Development. HOMER Manual, 21.

https://www.gsma.com/mobilefordevelopment/wp-content/uploads/2012/06/HOMER-

Software-Training-Guide-June 2011.

Kerdphol, T., Qudaih, Y., \& Mitani, Y. (2015). Battery energy storage system size optimization in microgrid using particle swarm optimization. IEEE PES Innovative Smart Grid Technologies Conference Europe, 2015-January (January). https://doi.org/10.1109/ISGTEurope.2014.7028895

Li, H., \& Hennessy, T. (2013). European town microgrid and energy storage application study. 2013 IEEE PES Innovative Smart Grid Technologies Conference, ISGT 2013, 1-6. https://doi.org/10.1109/ISGT.2013.6497890

Nfah, E. M., \& Ngundam, J. M. (2008). Modelling of wind/Diesel/battery hybrid power systems for far North Cameroon. Energy Conversion and Management, 49(6), 1295-1301. https://doi.org/10.1016/j.enconman.2008.01.007

Saviuc, I., Peremans, H., Van Passel, S., \& Milis, K. (2019). Economic Performance of using batteries in european residential microgrids under the net-metering scheme. Energies, 12(1). https://doi.org/10.3390/en12010165

Shaahid, S. M., \& El-Amin, I. (2009). Techno-economic evaluation of off-grid hybrid photovoltaicdiesel-battery power systems for rural electrification in Saudi Arabia-A way forward for sustainable development. Renewable and Sustainable Energy Reviews, 13(3), 625-633. https://doi.org/10.1016/j.rser.2007.11.017

Singh, G., \& Tiwari, A. N. (2017). Optimization of a smart grid distributed generation: Designing of a hybrid solar system for a building. 2017 1st International Conference on Electronics, Materials Engineering and Nano-Technology, IEMENTech 2017.

https://doi.org/10.1109/IEMENTECH.2017.8077007 